\title{
EFFECT OF STOCKING DENSITY ON GROWTH PERFORMANCE AND FEED UTILIZATION OF SEA BASS (Dicentrarchus labrax) IN CAGES SUSPENDED ON NATURAL POND
}

\author{
Ramadan M. Abou-Zied \\ Anim. Prod. Dept. Faculty of Agriculture, Fayoum University, Egypt
}

\section{ABSTRACT:}

Stocking density is considered a priority topic in aquaculture research due to its bearing on the welfare of farmed fish and the need for future recommendations governing stocking density management on fish farms. This study was carried out to investigate the growth performance and feed utilization response of sea bass (Dicentrarchus labrax) to different stocking densities. Two duplicate groups of sea bass (mean $\mathrm{BW}=32.83 \mathrm{~g})$ were reared in six cages $\left(2 \mathrm{~m}^{3}\right.$ each) suspended at natural pond with a proximate area of 20 hectare at three stocking densities $(30$, 45 and $60 \mathrm{fish} / \mathrm{m}^{3}$ equal to $1.0,1.5$ and $2.0 \mathrm{~kg} / \mathrm{m}^{3}$ ) for 225 days.

Significant differences $(\mathrm{P} \leq 0.05)$ on final fish weight, weight gain and daily gain were observed. Fish reared at the highest densities $\left(60 / \mathrm{m}^{3}\right)$ had the lowest mean final body weight $(225 \mathrm{~g})$ while those of the lowest densities $\left(30 / \mathrm{m}^{3}\right)$ showed the highest mean final body weight $(270 \mathrm{~g})$ while $\left(45 / \mathrm{m}^{3}\right)$ are in between. The differences between the lowest and higher density was $20 \%$. A similar tendency was observed for SGR, 0.85 and 0.92 in the highest and lowest densities, respectively.

Significant difference in FCR were observed groups ranging from 2.76 to 3.24 by about $17 \%$ between the lowest and highest density. Survival rate was insignificantly $(\mathrm{P} \leq 0.05)$ affected and was around $96 \%$ independently of the density and the period. Part of the mortality observed was due to fish jumping out of cages and other part after sampling. Regarding economic efficiency the net returns of cage improved with increasing density and the best net returns was observed with the density $45 / \mathrm{m}^{3}$ followed by densities 60 and $30 \mathrm{fish} / \mathrm{m}^{3}$ respectively.

In conclusion the best density was $45 \mathrm{fish} / \mathrm{m}^{3}$ which improved by $33 \%$ than the lowest density $\left(30 \mathrm{fish} / \mathrm{m}^{3}\right.$, one $\mathrm{kg} / \mathrm{m}^{3}$ ) and $17 \%$ than the highest density $\left(60 \mathrm{fish} / \mathrm{m}^{3}, 2.0 \mathrm{~kg} / \mathrm{m}^{3}\right.$ ) for economical evaluation.

Key words: Sea bass, growth performance, feed utilization and economic evaluation

\section{INTRODUCTION:}

European sea bass (Dicentrarchus labrax) is one of the most important species cultured in the European Union with an annual production around 51,000 tons at year 2006, (FAO, 2007). Wide competition among producing countries in the Mediterranean area (such as Greece, Italy and Turkey) and mainly reared through intensive techniques in both flow-through land-based systems and sea cages with stocking densities around $35-50 \mathrm{~kg} / \mathrm{m}^{3}$ (Lemarié et al., 1998; Paspatis et al., 2003). There is increasing interest from farming industries, retailers and consumers to investigate the quality differences between cultured and wild fish (Prescott and Bell 1992; Webster et al. 1993; Sylvia et al. 1995; Alasalvar et al. 2001, 2005).

Effect of stocking density on growth performance was illustrated by many authors different in densities used $/ \mathrm{m}^{3}$ but all of them used recirculation intensive

Fayoum J. Agric. Res. \& Dev., Vol.24, No.1, January, 2010 
system (Lemarié et al., 1998; Paspatis et al., 2003, Lupatsch et al., 2010, Wedemeyer, 1997; Ashley, 2007, Ellis et al., 2002; Turnbull et al., 2005; North $\boldsymbol{e t}$ al., 2006). No references are available about production of sea bass under natural system in cages on lacks or sea.

The great importance of stocking density in achieving the aims of the controlled production of several fish species has been reported by several investigators (Kilambi et al., 1977; Papoutsoglou et al., 1979, 1980, 1987, 1990; Carr and Aldrich, 1982; Holm et al., 1990; Pickering, 1990, Christiansen et al., 1992; Jorgensen et al., 1993). In most of the fish species so far investigated, an inverse correlation between growth rate and stocking density has been found due to decreased food utilization (Carr and Aldrich, 1982; Mackintosh and De Silva, 1984; Papoutsoglou et al., 1987, 1990).

Stocking density is widely recognized as a critical husbandry factor in intensive aquaculture because it represents a potential source of chronic stress, which may affect physiology and behaviour of farmed fish (Wedemeyer, 1997; Schreck et al., 1997; Ellis et al., 2002). However, highly intensive recirculation systems of densities up to $100 \mathrm{~kg} / \mathrm{m}^{3}$ are being developed (Blancheton, 2000). It has been demonstrated that rearing at inappropriate stocking densities may impair the growth, reduce immune competence and induce abnormal behaviour (Procarione et al., 1999; Irwin et al., 1999; Montero et al., 1999; Ellis et al., 2002; Iguchi et al., 2003; Barcellos et al., 2004; Kristiansen et al., 2004; Schram et al., 2006).

Generally high density is considered as a potential source of stress, with a negative effect on fish growth rate (Lefrançois et al., 2001) and survival and feeding rates (Rowland et al., 2006).

European sea bass Dicentrarchus labrax show phase inversion in their feeding rhythms on a seasonal basis: fish which were diurnal in summer and autumn, changed to nocturnal in winter, and returned to being diurnal in later spring Sa'nchez-V'azquez et al., 1998.

Daily feed intake and specific growth rate decreases were observed at increasing density levels on several species such as Atlantic cod (Gadus morhua L.) (Lambert and Dutil, 2001), brook charr (Salvelinus fontinalis) (Vijayan and Leatherland, 1988), gilthead sea-bream (Sparus aurata) (Canario et al., 1998) and largemouth bass (Micropterus salmoides) (Petit et al., 2001).

The aim of this work is to study the possible production of sea bass under Fayoum conditions for first time in cages on Rayyan lack under different stocking densities.

\section{MATERIALS AND METHODS:}

This study investigated the effect of stocking density on growth performance and feed utilization of sea bass reared in cages under natural water condition. It started on 25/9/2008 till 8/5/2009, a proximally 225 days in Rayyan region Fayoum Governorate.

Sea bass fingerlings were obtained from El-Wafaa farm company, ElBehira Governorate, Egypt. A total of 270 sea bass fingerling with an average body weight of $32.83 \mathrm{~g}$ were distributed in 6 cages $2 \times 1 \times 1 \mathrm{~m}$ (tall $\times$ width $\times$ depth) suspended in a natural pond approximately 20 hectare at three stocking density $\left(30,45\right.$ and $60 \mathrm{fish} / \mathrm{m}^{3}$ equal $1.0 \mathrm{~kg}, 1.5 \mathrm{~kg}$ and $2.0 \mathrm{~kg} / \mathrm{m}^{3}$ ) using two cages/density. Fish fed a diet contained $45 \% \mathrm{CP}$ (Table 1) at a rate of $3 \%$ of body weight twice a day.

Fayoum J. Agric. Res. \& Dev., Vol.24, No.1, January, 2010 
Fish weighed every two week in order to adjust the feed in the cage according to a new weight obtained.

Statistical analyses were performed using SPSS, 1997. Statistical significant between treatments was evaluated at the $5 \%$ probability level.

\section{RESULTS AND DISCUSSION:}

Average water salinity was $15.2-16.5 \%$ during the experiment period, the temperature was stable around $27-30^{\circ}$ in summer and $15-18^{\circ}$ in winter and. oxygen concentration was suitable (5.3-6.8), $\mathrm{pH}$ around 7.5

\section{Growth performance:}

The effect of stocking density on growth performance was shown in Table 2. Significant differences on final fish weight, weight gain and daily gain were observed between groups of the two highest and the lowest stocking densities. Final mean weight showed a decreasing tendency with increasing stocking density. Fish reared at the highest densities $\left(60 \mathrm{fish} / \mathrm{m}^{3}\right)$ had the lowest mean final body weight $(225 \mathrm{~g})$ while those of the lowest densities $\left(30 \mathrm{fish} / \mathrm{m}^{3}\right)$ showed the highest mean final body weight $(270 \mathrm{~g})$ while $\left(45 \mathrm{fish} / \mathrm{m}^{3}\right)$ was in between. The differences between the lowest and highest density were $20 \%$ in final weight. A similar tendency was observed for SGR, 0.85 and 0.94 with (45 fish $\left./ \mathrm{m}^{3}\right)$ and $\left(30 \mathrm{fish} / \mathrm{m}^{3}\right)$ respectively but the highest density was in between.

Table (1). Composition and proximate analysis of feed (on as fed basis).

\begin{tabular}{|l|c|}
\hline \multicolumn{1}{|c|}{ Items } & $\%$ \\
\hline Ingredients & 22 \\
Fish meal & 24 \\
Soybean & 10 \\
yellow corn & 30 \\
Gluten & 2 \\
vit \& min & 1 \\
Calcium phosphate & 11 \\
Linseed oil & \\
Chemical composition & 9.44 \\
DM & 45.18 \\
Crude protein, CP & 15.66 \\
Ether extract, EE & 7.69 \\
Ash & 2.20 \\
Crude fiber, CF & 19.83 \\
Nitrogen free extract. NFE & 4.810 \\
GE, kcal/g* & \\
\hline
\end{tabular}

1, Calculated by differences * Calculated according to NRC, 1993.

The results obtained clearly show that the growth rate of European sea bass juveniles increased with decreasing stocking density. This finding agrees with growth studies reported by Wallace et al., 1988; Baker and Ayles, 1990; Jorgensen et al., 1993, while growth rates inversely associated with stocking density have been reported for the majority of the fish species studied (Refstie and Kittelsen, 1976; Papoutsoglou et al., 1979, 1980, 1987, 1990; Fagerland et al., 1981; Leatherland and Cho, 1985; Vijayan and Leatherland, 1988; Erlod et al., 1989; Zoccarato et al., 1994; Al-Jerian, 1996). Reasons for the growth performance of sea bass juveniles observed in the present study may be due to that low density fish takes better requirements of oxygen and others namely feed.

Fayoum J. Agric. Res. \& Dev., Vol.24, No.1, January, 2010 
Table (2). Effect of stock density on productive performance of sea bass through the experimental period.

\begin{tabular}{|c|c|c|c|c|}
\hline \multirow{2}{*}{ Parameters } & \multicolumn{3}{|c|}{ Stocking density/ $\mathrm{m}^{3}$} & \multirow{2}{*}{ SED } \\
\hline & 30 (1 kg) & $45(1.5 \mathrm{~kg})$ & $60(2 \mathrm{~kg})$ & \\
\hline Initial mean body weight, $\mathrm{g}$ & 34 & 31 & 33.5 & 1.22 \\
\hline $\begin{array}{l}\text { Final mean body weight, } \mathbf{g} \\
\text { Total gain, } \mathbf{g}^{(1)} \\
\text { Daily gain, } \mathbf{g}^{(2)} \\
\text { SGR, \% }\end{array}$ & $\begin{array}{r}270^{\mathrm{a}} \\
236^{\mathrm{a}} \\
1.20^{\mathrm{a}} \\
0.92^{\mathrm{ab}}\end{array}$ & $\begin{array}{l}257.5^{\mathrm{a}} \\
226.5^{\mathrm{a}} \\
1.14^{\mathrm{a}} \\
0.94^{\mathrm{a}}\end{array}$ & $\begin{array}{c}225^{\mathrm{D}} \\
191.5^{\mathrm{D}} \\
1.00^{\mathrm{D}} \\
0.85^{\mathrm{D}}\end{array}$ & $\begin{array}{r}9.35 \\
10.12 \\
0.04 \\
0.02\end{array}$ \\
\hline
\end{tabular}

* Average in the same row having different superscripts differ significantly $\mathrm{P} \leq 0.05$.

* SED is the standard error of difference

Experimental period $=225$ days

(1) $=$ Final weight - Initial weight

(2) $=$ Total gain, $\mathrm{g} /$ period in days

$(3)=100(\ln$ Final weight-ln Initial weight $) /$ period in days, where $\ln$ is the natural $\log$.

\section{Feed utilization:}

The effect of stocking density on feed utilization was shown in Table 3. Significant differences in feed conversion ratio (FCR) was observed between groups of the two highest and the lowest stocking densities. The FCR improved with low stocking density (2.76) than high socking density (3.24) by difference about $17 \%$ between them.

The survival rate was insignificantly $(\mathrm{P} \leq 0.05)$ affected. It was around $96 \%$ independently of the density and the period. Part of the mortalities observed was due to fish jumping out of cages and other part after sampling.

Table (3). Effect of stock density on feed utilization of sea bass through the experimental period.

\begin{tabular}{|c|c|c|c|c|}
\hline \multirow{2}{*}{ Parameters } & \multicolumn{3}{|c|}{ Stocking density/ $\mathrm{m}^{3}$} & \multirow{2}{*}{ SED } \\
\hline & $30(1 \mathrm{~kg})$ & $45(1.5 \mathrm{~kg})$ & $60(2 \mathrm{~kg})$ & \\
\hline Feed intake, g/fish & 650 & 642.5 & 620 & 7.36 \\
\hline $\begin{array}{l}\text { FCR } \\
\text { Survival rate } \% \\
\text { Feed intake, kg/cage }\end{array}$ & $\begin{array}{l}2.76^{\mathrm{D}} \\
96.5 \\
39.0\end{array}$ & $\begin{array}{l}2.84^{\mathrm{D}} \\
96.5 \\
57.8\end{array}$ & $\begin{array}{c}3.24^{\mathrm{a}} \\
96.75 \\
74.4\end{array}$ & $\begin{array}{c}0.13 \\
1.93 \\
---\end{array}$ \\
\hline
\end{tabular}

* Average in the same row having different superscripts differ significantly $\mathrm{P} \leq 0.05$.

* SED is the standard error of difference

\section{Economic evaluation:}

The effect of stocking density on economic evaluation was shown in Table 4. Although increasing final body weight of the lowest density, the net returns of cage improved with increasing density and the best net returns was observed with the density $45 \mathrm{fish} / \mathrm{m}^{3}$ followed by densities 60 and $30 \mathrm{fish} / \mathrm{m}^{3}$ respectively.

In conclusion the best density was $45 \mathrm{fish} / \mathrm{m}^{3}$ which net returns improved by $33 \%$ than the lowest density ( $30 \mathrm{fish} / \mathrm{m}^{3}$, one $\mathrm{kg} / \mathrm{m}^{3}$ ) and $17 \%$ than the highest density $\left(60 \mathrm{fish} / \mathrm{m}^{3}, 2.0 \mathrm{~kg} / \mathrm{m}^{3}\right)$. 
EFFECT OF STOCKING DENSITY ON GROWTH PERFORMANCE.... 124

Table (4). Effect of stock density on economic efficiency of sea bass through the experimental period.

\begin{tabular}{|c|c|c|c|}
\hline \multirow{2}{*}{ Parameters } & \multicolumn{3}{|c|}{ Stocking density/ $\mathrm{m}^{3}$} \\
\hline & $30(1 \mathrm{~kg})$ & $45(1.5 \mathrm{~kg})$ & $60(2 \mathrm{~kg})$ \\
\hline \multicolumn{4}{|l|}{ Costs, L.E/cage } \\
\hline Feed & 312 & 462.4 & 595.2 \\
\hline Fish & 120 & 180 & 240 \\
\hline Other costs & 10 & 10 & 10 \\
\hline Total costs, L.E. & 442 & 652.4 & 845.2 \\
\hline Cage biomass, kg & 16.2 & 23.18 & 27.0 \\
\hline Selling price, L.E/ cage & 648 & 927 & 1080 \\
\hline Net returns/cage & 206 & 274.6 & 234.8 \\
\hline
\end{tabular}

Price of one kg selling fish $=40$ L.E

Price of $\mathrm{kg}$ feed $=8 \mathrm{~L} . \mathrm{E}$

\section{REFERENCES:}

Alasalvar C., Taylor, K.D.A., Oksuz, A., Garthwaite T., Alexis M.N., Grigorakis K. (2001). Freshness assessment of cultured sea bream (Sparus aurata) by chemical, physical and sensory methods. Food Chem., 72: 33-40

Alasalvar C., Taylor, K.D.A., Shahidi, F. (2005). Comparison of volatiles of cultured and wild sea Bream (Sparus aurata) during storage in ice by dynamic headspace analysis/gas chromatography-mass spectrometry. J Agric Food Chem., 53: 26162622

Al-Jerian, A.A. (1996). Effect of stocking density on growth of the Nile tilapia Oreochromis niloticus (L.), reared in glass cages. Pak. J. Zool., 28: 182-184.

Ashley, P.J. (2007). Fish welfare: current issues in aquaculture. Applied Animal Behaviour Science 104: 199-235.

Baker, R.F., Ayles, G.B. (1990). The effects of carrying density and loading level on the growth of Arctic charr (Salvelinus alpinus L.) and rainbow trout (Oncorhynchus mykiss). World Aquacult., 21: 58-62.

Barcellos, L.J., Kreutz, L.C., de Souza, C., Rodrigues, L.B., Fioreze, I., Quevedo, R.M., Cericato, L., Soso, A.B., Fagundes, M., Conrad, J., Lacerda, L.A., Terra, S. (2004). Hematological changes in jundia (Rhamdia quelen Quoy and Gaimard Pimelodidae) after acute and chronic stress caused by usual aquacultural management, with emphasis on immunosuppressive effects. Aquaculture 237: 229236.

Blancheton, J.P. (2000). Developments in recirculation systems for Mediterranean fish species. Aquaculture Engineering, 22: 17-31.

Canario, A.V.M., Condec,A., J., Power, D.M., Ingleton, P.M. (1998). The effect of stocking density on growth in the gilthead sea-bream, Sparus aurata (L.). Aquaculture Research, 29: 177-181.

Carr, B.A., Aldrich, D.V. (1982). Population density effects on the behavior and feeding of young striped mullet (Mugil cephalus) in 37.8 liter aquaria. J. World Maricult. Soc., 13: 254-260.

Christiansen, J.S., Svendsen, Y.S., Jobling, M. (1992). The combined effect of stocking density and sustained exercise on the behavior, food intake and growth of juvenile Arctic charr (Salvelinus alpinus L.). Can. J. Zool., 70: 115-122.

Ellis, T., North, B., Scott, A.P., Bromage, N.R., Porter, M., Gadd, D. (2002). The relationships between stocking density and welfare in farmed rainbow trout. J. Fish Biol., 61: 493-531.

Fayoum J. Agric. Res. \& Dev., Vol.24, No.1, January, 2010 
Erlod, J.H., Ostergaard, D.E., Schneider, C.P. (1989). Effect of rearing density on poststocking survival of lake trout in Lake Ontario. Prog. Fish Cult., 51: 189-193.

Fagerland, V.H.M., Mcbride, J.R., Stone, E.T. (1981). Stress-related effects of hatchery rearing density on coho salmon. Trans. Am. Fish. Soc. 110, 644-649.

FAO (2007). Fisheries department, Fishery Information, Data and Statistics Unit. Fish stat Plus: Universal software for fishery statistical time series. Version 2:32

Holm, J.C., Refstie, T., Bo, S. (1990). The effect of fish density and feeding regimes on individual growth rate and mortality in rainbow trout (Oncorhynchus mykiss). Aquaculture, 89: 225-232.

Iguchi, K., Ogawa, K., Nagae, M., Ito, F. (2003). The influence of rearing density on stress response and disease susceptibility of ayu (Plecoglossus altivelis). Aquaculture, 220: 515-523.

Irwin, S., O'Halloran, J., FitzGerald, R.D. (1999). Stocking density, growth and growth variation in juvenile turbot, Scophthalmus maximus (Rafinesque). Aquaculture, 178: 77-88.

Jorgensen, E.H., Christiansen, J.S., Jobling, M. (1993). Effects of stocking density on food intake, growth performance and oxygen consumption in Arctic charr (Salvelinus alpinus). Aquaculture, 110: 191-204.

Jorgensen, E.H., Christiansen, J.S., Jobling, M. (1993). Effects of stocking density on food intake, growth performance and oxygen consumption in Arctic charr (Sal6elinus alpinus). Aquaculture 110, 191-204.

Kilambi, R.V., Adams, J.C., Brown, A.V., Wickizer, W.A. (1977). Effects of stocking density and cage size on growth, feed conversion and production of rainbow trout and channel catfish. Prog. Fish Cult., 39: 62-66

Kristiansen, T.S., Ferno, A., Holm, J.C., Privitera, L., Bakke, S., Fosseidengen, J.E. (2004). Swimming behaviour as an indicator of low growth rate and impaired welfare in Atlantic halibut (Hippoglossus hippoglossus L.) reared at three stocking densities. Aquaculture, 230: 137-151.

Lambert, Y., Dutil, J.D. (2001). Food intake and growth of adult Atlantic cod (Gadus morhua L.) reared under different conditions of stocking density, feeding frequency and size-grading. Aquaculture, 192: 233-247.

Leatherland, J.F., Cho, C.Y. (1985). Effects of rearing density on thyroid and interrenal gland activity and plasma hepatic metabolite levels in rainbow trout Salmo gairdneri Richardson. J. Fish Biol., 27: 583-592.

Lefrançois, C., Claireaux, G., Mercier, C., Aubin, J. (2001). Effect of density on the routine metabolic expenditure of farmed rainbow trout (Oncorhynchus mykiss). Aquaculture, 195: 269-277.

Lemarié, G., Martin, J.L., Dutto, G., Garidou, C. (1998). Nitrogenous and phosphorous waste production in a flow-through land-based farm of European sea bass (Dicentrarchus labrax). Aquatic Living Resources, 11: 247-254.

Lupatsch, I., Santos, G.A., Schrama, J.W. and Verreth, J.A.J. (2010). Effect of stocking density and feeding level on energy expenditure and stress responsiveness in European sea bass Dicentrarchus labrax. Aquaculture, 298: 245-250

Mackintosh, D.J., De Silva, S.S. (1984). The influence of stocking density and food ratio on fry survival and growth in Oreochromis mossambicus female $\times O$. aureus male hybrids reared in a closed circulated system. Aquaculture, 41: 345-358.

Montero, D., Izquierdo, M.S., Tort, L., Robaina, L., Vergara, J.M. (1999). High stocking density produces crowding stress altering some physiological and biochemical parameters in gilthead seabream, Sparus aurata, juveniles. Fish Physiol. Biochem., 20: 53-60.

Fayoum J. Agric. Res. \& Dev., Vol.24, No.1, January, 2010 
North, B.P., Turnbull, J.F., Ellis, T., Porter,M.J., Migaud, H., Bron, J., Bromage, N.R., (2006). The impact of stocking density on the welfare of rainbow trout (Oncorhynchus mykiss). Aquaculture, 255: 466-479.

NRC (1993). Nutrient requirements of fish. Committee on Animal Nutrition Board on Agriculture National Research Council National Academy Press, Washington DC, USA.

Papoutsoglou, S.E., Papaparaskeva-Papoutsoglou, E., Alexis, M. (1980). Rainbow trout growth and production in relation to water volume unit. Thalassographica, 2: $43-52$.

Papoutsoglou, S.E., Papaparaskeva-Papoutsoglou, E., Alexis, M.N. (1987). Effect of density on growth rate and production of rainbow trout (Salmo gairdneri Rich.) over a full rearing period. Aquaculture, 66: 9-17.

Papoutsoglou, S.E., Papaparaskeva-Papoutsoglou, E., Dendrinos, P.K. (1979). Studies on the effect of density on body composition, growth rate and survival of rainbow trout fry in semi closed system. Thalassographica, 3: 43-56.

Papoutsoglou, S.E., Voutsinos, G.A., Panetsos, F. (1990). The effect of photoperiod and density on growth rate of Oreochromis aureus (Steindachner) reared in a closed water system. Anim. Sci. Rev., 11: 73-87

Paspatis, M., Boujard, T., Maragoudaki, D., Blanchard, G., Kentouri, M. (2003). Do stocking density and feed reward level affect growth and feeding of self-fed juvenile European sea bass? Aquaculture, 216: 103-113.

Petit, G., Beauchaud, M., Buisson, B. (2001). Density effects on food intake and growth of largemouth bass (Micropterus salmoides). Aquaculture Research, 32: 495-497 (Short communication).

Pickering, A.D. (1990). Stress and supression of somatic growth in teleost fish. In: Epple, A., Scanes, C.G., Stetson, M.H. (Eds.), Progress in Comparative Endocrinology. Wiley, New York, pp. 473-479.

Prescott J., Bell J.D. (1992). Sensory evaluation of Australian snapper (Pagrus auratus) raised in captivity. Asian Food J., 7:11-113

Procarione, L.S., Barry, T.P., Malison, J.A. (1999). Effects of high rearing densities and loading rates on the growth and stress responses of juvenile rainbow trout. North American Journal of Aquaculture, 61: 91-96.

Refstie, T., Kittelsen, A. (1976). Effect of density on growth and survival of artificially reared Atlantic salmon. Aquaculture, 8: 319-326

Rowland, S.J., Mifsud, C., Nixon, M., Boyd, P. (2006). Effects of stocking density on the performance of the Australian freshwater silver perch (Bidyanus bidyanus) in cages. Aquaculture, 253: 301-308.

Sa'nchez-V'azquez, F.J., Azzaydi, M., Martinez, F.J., Zamora, S., Madrid, J.A. (1998). Annual rhythms of demand-feeding activity in sea bass: evidence of a seasonal phase inversion of the diet feeding pattern. Chronobiol. Int., 15: 607-622.

Schram, E., Van der Heul, J.W., Kamstra, A., Verdegem, M.C.J. (2006). Stocking density-dependent growth of Dover sole (Solea solea). Aquaculture, 252: 339-347.

Schreck, C.B., Olla, B.L., Davis, M.W. (1997). Behavioral responses to stress. In: Iwana, G.K., Pickering, A.D., Sumpter, J.P., Schreck, C.B. (Eds.), Fish stress and health in aquaculture. Society for Experimental Biology, Seminar Series 62, Cambridge University Press, Cambridge, pp. 145-170.

SPSS. (1997). Statistical Package For Social Science (for Windows). Release 8.0 Copyright (C), SPSS Inc., Chicago, USA.

Sylvia G., Morrisey M.T., Graham T., Garcia S. (1995). Organoleptic qualities of farmed and wild salmon. J Aquat. Food Prod. Technol., 4: 51-64

Fayoum J. Agric. Res. \& Dev., Vol.24, No.1, January, 2010 
Turnbull, J., Bell, A., Adams, C., Bron, J., Huntingford, F. (2005). Stocking density and welfare of cage farmed Atlantic salmon: application of a multivariate analysis. Aquaculture, 243: 121-132.

Vijayan, M.M., Leatherland, J.F. (1988). Effect of stocking density on the growth and stress-response in brook charr, Salvelinus fontinalis. Aquaculture, 75: 159-170.

Wallace, J.C., Kolbeinshavn, A., Reisnes, T.G. (1988). The effects of stocking density on early growth in Arctic charr, Salvelinus alpinus (L.). Aquaculture, 73: 101-110.

Webster C.D., Tidwell J.H., Goodgame L.S. (1993). Growth, body composition and organoleptic evaluation of channel catfish fed diets containing different percentages of distillers' grains with solubles. Prog. Fish. Cult., 55: 95-100.

Wedemeyer, G.A. (1997). Effects of rearing conditions on the health and physiological quality of fish in intensive culture. In: Iwama, G.K., Pickering, A.D., Sumpter, J.P., Schreck, C.B. (Eds.), Society for Experimental Biology Seminar Series, vol. 62. Cambridge Univ. Press, Cambridge, U.K., pp. 35-71.

Zoccarato, I., Benatti, G., Bianchini, M.L., Boccignone, M., Conti, A., Napolitano, R., Palmegiano, G.B. (1994). Differences in performance, flesh composition and water output quality in relation to density and feeding level in rainbow trout, Oncorhynchus mykiss (Walbaum). Farming Aquacult. Fish. Manag., 25: 239-647.

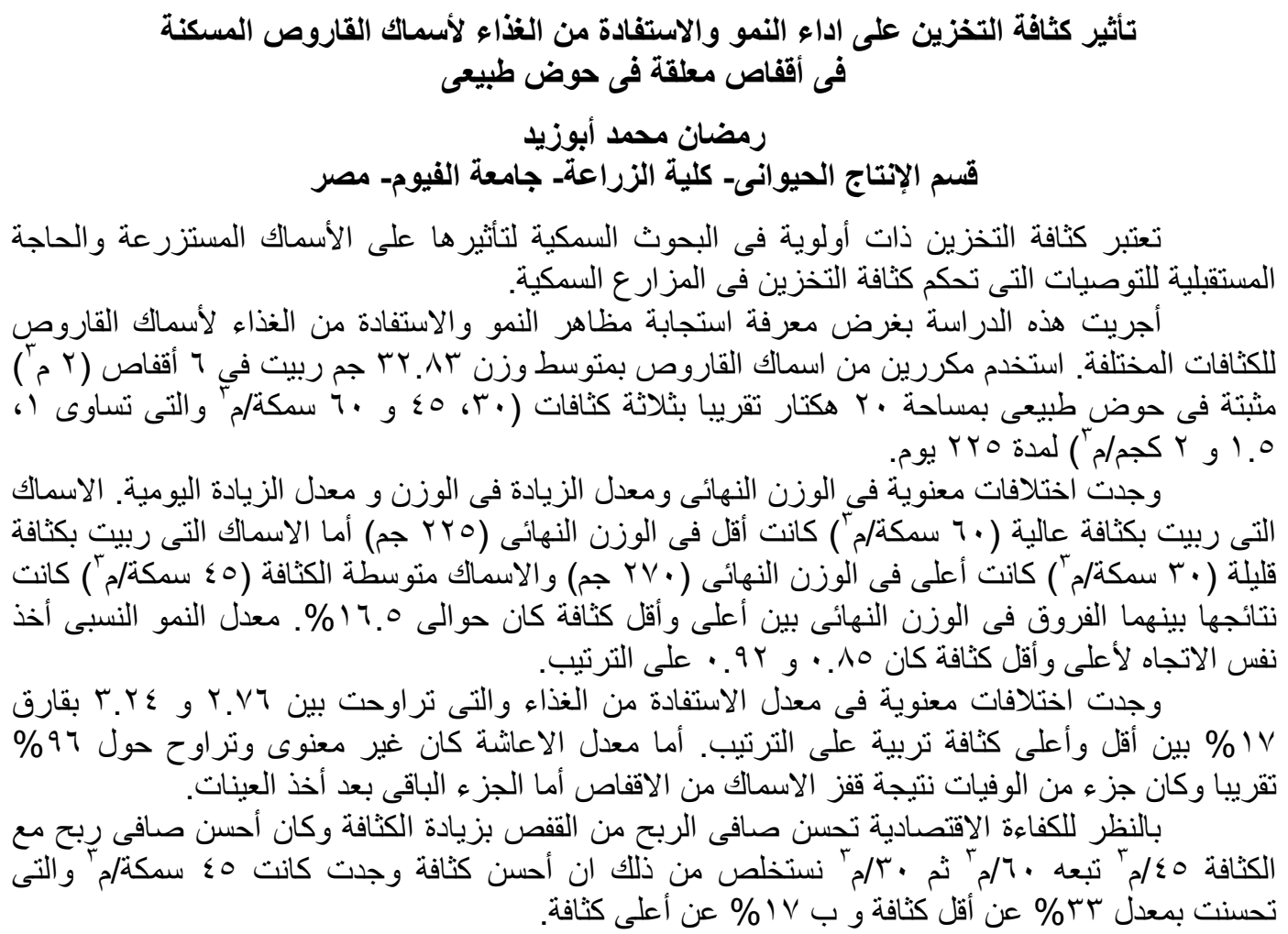

